\title{
Development of spray-dried co-precipitate of amorphous celecoxib containing storage and compression stabilizers
}

RAVINDRA S. DHUMAL

SHAMKANT L. SHIMPI

ANANT R. PARADKAR*

Department of Pharmaceutics

Bharati Vidyapeeth University

Poona College of Pharmacy and Research

Centre, Erandawane, Pune-411038

Maharashtra, India

Accepted June 11, 2007
The purpose of this study was to obtain an amorphous system with minimum unit operations that will prevent recrystallization of amorphous drugs since preparation, during processing (compression) and further storage. Amorphous celecoxib, solid dispersion (SD) of celecoxib with polyvinyl pyrrollidone (PVP) and co-precipitate with PVP and carrageenan (CAR) in different ratios were prepared by the spray drying technique and compressed into tablets. Saturation solubility and dissolution studies were performed to differentiate performance after processing. Differential scanning calorimetry and X-ray powder difraction revealed the amorphous form of celecoxib, whereas infrared spectroscopy revealed hydrogen bonding between celecoxib and PVP. The dissolution profile of the solid dispersion and co-precipitate improved compared to celecoxib and amorphous celecoxib. Amorphous celecoxib was not stable on storage whereas the solid dispersion and co-precipitate powders were stable for 3 months. Tablets of the solid dispersion of celecoxib with PVP and physical mixture with PVP and carrageenan showed better resistance to recrystallization than amorphous celecoxib during compression but recrystallized on storage. However, tablets of co-precipitate with PVP and carageenan showed no evidence of crystallinity during stability studies with comparable dissolution profiles. This extraordinary stability of spray-dried co-precipitate tablets may be attributed to the cushioning action provided by the viscoelastic polymer CAR and hydrogen bonding interaction between celecoxib and PVP. The present study demonstrates the synergistic effect of combining two types of stabilizers, PVP and CAR, on the stability of amorphous drug during compression and storage as compared to their effect when used alone.

Keywords: celecoxib, amorphous, solid dispersion, co-precipitate, PVP, carrageenan, compression, stability, tableting

\footnotetext{
* Correspondence, e-mail: arparadkar@rediffmail.com
} 
Delivery of poorly soluble drugs is one of the greatest challenges confronting formulation scientists in pharmaceutical industries. Low solubility and/or dissolution rate in the gastrointestinal tract compromise oral bioavailability. Various techniques are used to develop a dosage form that can improve the dissolution rate of drugs. Development of amorphous solids or glasses of crystalline drugs is one of the most widely used approaches $(1,2)$. Amorphous solids lack three-dimensional long-range molecular orders and have high-energy states and hence exhibit increased dissolution rate. Amorphous solids may be obtained by melt quenching, grinding (3), lyophilization (4), spray drying (5), sonocrystallization and melt sonocrystallization (6), where high levels of super saturation are achieved, favoring formation of amorphous form. Higher energy content of amorphous or vitreous states is responsible for its tendency to devetrify during storage. Similarly, energy provided by unit operations such as milling, mixing, sifting and compression involved in processing accelerate the devetrification process. Therefore, various attempts have been made to stabilize the solids in the amorphous state.

Development of solid dispersion (SD) with hydrophilic polymers like polyvinyl pyrrollidone (PVP) (5), polyethylene glycol (PEG) (7) and polyvinyl alcohol (PVA) (8) is the preferred approach to improve stability of the amorphous state. Increase in glass transition temperature $\left(T_{\mathrm{g}}\right)(5)$, immobilization of drug molecules (9) and/or hydrogen bonding $(10,11)$ with such polymers are commonly proposed mechanisms for stabilization. The polymers used as stabilizers may cause processing problems like sticking to the punches during compression and may also lead to delayed disintegration time (12). In an attempt to overcome these problems, polymers were replaced by small amounts of hydrophilic lipids like Gelucire for stabilization of drugs in the amorphous state (9). However, prevention of recrystallization during pharmaceutical processing remained the main hurdle. Numerous examples of polymorphic transitions during processing are reported in literature (13). Polymorphic transformations of chlorpropamide (14), amorphous indomethacin (15) and phenobarbital (16) during compression are well known. Even irregular plasma levels owing to differences in dissolution rates associated with the production of differing polymorphs of carbamazepine by tablet manufacturing operations have been reported (17). Detailed studies to investigate polymorphic changes during tableting of caffeine, sulfabenzamide, and maprotiline hydrochloride revealed that the extent of transformation depended on the pressure applied during compression (18).

Viscoelastic polymers like carrageenan (CAR) have been tested as compression stabilizers. Potential of CAR in the form of a physical mixture (PM) to minimize devetrification and polymorphic transformation during compression has been reported $(19,20)$. This special ability was attributed to high elasticity during tableting and also to high elastic recovery of CAR during decompression. However, the system in the form of PM could prolong recrystallization by only few days, achieving limited success. Considering these facts, it is a challenging job to maintain the amorphous state of a drug from the stage of its formation to compression and during storage. Therefore, the aim of the present work is to combine two types of stabilizers acting during compression and also during storage and minimize the number of unit operations between the generation of the amorphous state and compression. 


\section{EXPERIMENTAL}

\section{Materials}

Celecoxib (CEL) was a generous gift from Lupin Research Park (India), while CAR (Gelcarin ${ }^{\circledR}$ GP-379) was a gift sample from FMC Corporation, Philadelphia, PA (through Signet Chemical, India) and PVP K 30 from BASF, Germany. Tableting excipients (lactose, magnessium stearate and talc) were supplied by Get-Rid Pharmaceuticals Ltd. (India). All other chemicals and solvents were of analytical grade.

\section{Preparation of solid dispersion, co-precipitate and physical mixture}

CEL alone or in combination with PVP (1:0.5, 1:1 and 1:1.5, parts by mass) was dissolved in a sufficient amount of methanol to obtain a clear solution and spray-dried to obtain amorphous celecoxib (ACEL) or solid dispersion of celecoxib with PVP (SD-CP), respectively. To the clear solution of CEL and PVP (1:1 parts by mass) in methanol, CAR ( 2 parts by mass) was added slowly under stirring to obtain uniform dispersion and spray-dried to obtain spray-dried co-precipitate (SD-CPT) of CEL with PVP and CAR. Spray drying was done using a laboratory scale spray drier (Jay Instruments \& Systems Pvt. Ltd., India) under the following conditions: inlet temperature $100{ }^{\circ} \mathrm{C}$, outlet temperature $90{ }^{\circ} \mathrm{C}$, feed rate $4-6 \mathrm{~mL} \mathrm{~min}^{-1}$, atomization air pressure $98.07 \mathrm{kPa}$ and aspiration pressure $-1.96 \mathrm{kPa}$.

All the samples were kept in vacuum dryer for 24 hours to remove residual solvent and stored in a dessicator until further study. Physical mixture of celecoxib with PVP and CAR (PM-CPC) in the ratio 1:1:2 was prepared by mixing them gently. All the samples were analyzed for crystallinity immediately after preparation by DSC and XRPD.

\section{Loading efficiency}

SDs equivalent to $10 \mathrm{mg}$ of CEL were weighed accurately, dissolved in methanol, suitably diluted and analyzed for drug content with a UV-spectrophotometer (V-530, JASCO, Japan) at $248 \mathrm{~nm}$.

\section{Saturation solubility}

Apparent saturation solubility measurements were carried out for CEL, ACEL, SD-CP and SD-CPT. A known excess sample was added to $10 \mathrm{~mL}$ of distilled water and stirred at $20 \mathrm{rpm}$ in a water bath $\left(37^{\circ} \mathrm{C}\right)$ for $48 \mathrm{~h}$. Samples were filtered through $0.45-\mu \mathrm{m}$ filter paper, suitably diluted and analyzed at different time intervals at $248 \mathrm{~nm}$.

\section{Thermogravimetric analysis (TGA)}

To determine the residual solvent in spray-dried samples, thermogravimetric analysis was performed using a TA-60WS Thermogravimetric analyzer (Shimadzu, Japan). Samples (approximately $30-40 \mathrm{mg}$ ) were heated in a platinum crucible in nitrogen atmosphere and the loss of mass as a function of temperature was recorded. 


\section{Tablet formulations}

ACEL, SD-CP, SD-CPT and PMs (equivalent to $5 \mathrm{mg}$ CEL) were compressed into tablets using suitable tableting excipients as diluent (lactose), lubricant and glidant (talc and magnessium stearate) with a 10-station, single rotary, B-tooling tablet machine (Rimek, MINI PRESS-I, Karnavati Engineering Ltd., India). Tablets were evaluated for uniformity in mass, thickness and hardness using a diametrical hardness tester (PTB, Pharmatest, India) and for friability using an EF-2, Friabilator (Electrolab, India).

\section{Diffuse reflectance infrared Fourier transform spectroscopy (DRIFTS)}

The DRIFTS spectra were obtained, after appropriate background subtraction using an FTIR spectrometer (FT/IR-4100, Jasco, Japan). Samples were mixed with dry potassium bromide and scanned from $4000-400 \mathrm{~cm}^{-1}$.

\section{Differential scanning calorimetry (DSC)}

DSC studies were carried out using a Mettler-Toledo DSC 821e instrument equipped with an intracooler (Mettler-Toledo, Switzerland). Indium and zinc standards were used to calibrate the DSC temperature and enthalpy scale. The samples were hermetically sealed in aluminum pans and heated at a constant rate of $10^{\circ} \mathrm{C} \mathrm{min}-1$ over a temperature range of $25-180^{\circ} \mathrm{C}$. Inert atmosphere was maintained by purging nitrogen gas at a flow rate of $50 \mathrm{~mL} \mathrm{~min}{ }^{-1}$.

\section{X-ray powder diffraction (XRPD)}

The XRPD patterns were recorded on an X-ray diffractometer (PW 1729, Philips, The Netherlands). Samples were irradiated with monochromatized $\mathrm{CuK} \alpha$ radiation $(1.542$ $\AA$ ) and analyzed between 2 to $50^{\circ} 2 \theta$. The voltage and current used were $30 \mathrm{kV}$ and 30 $\mathrm{mA}$, respectively.

\section{In vitro drug release}

The dissolution studies were performed using USP 24 a type II dissolution test apparatus (21) (TDT-06P, Electrolab, India). All powder preparations and their corresponding tablets were placed in a dissolution vessel containing $900 \mathrm{~mL}$ phosphate buffer $(\mathrm{pH}$ 6.8), maintained at $37 \pm 0.5{ }^{\circ} \mathrm{C}$ and stirred at $100 \mathrm{rpm}$. Samples were collected periodically and replaced with a fresh dissolution medium. After filtration through $0.45-\mu \mathrm{m}$ filter paper, concentration of CEL was determined at $248 \mathrm{~nm}$. Data was analyzed using the PCP-Disso software (V3, Poona College of Pharmacy, Pune, India).

\section{Stability study}

All preparations and the corresponding tablets were packed in aluminum foil. Samples were monitored up to 3 months at ambient temperature and relative humidity (30 $\left.{ }^{\circ} \mathrm{C} / 65 \% \mathrm{RH}\right)$. Samples were removed periodically (15 days, 1 month and 3 months) and characterized for dissolution and the presence of crystallinity by DSC and XRPD studies in comparison with the initial sample. 
R. S. Dhumal et al.: Development of spray-dried co-precipitate of amorphous celecoxib containing storage and compression stabilizers, Acta Pharm. 57 (2007) 287-300.

\section{RESULTS AND DISCUSSION}

CEL alone and in various ratios with PVP, as a stabilizer $(1: 0.5,1: 1$ and 1:1.5, $\mathrm{m} / \mathrm{m})$, was spray-dried. The process was optimized on the basis of production yield, powder characteristics, drug content, saturation solubility, dissolution profile and feasibility of processing into tablets (directly compressible without need of higher diluent ratio). Production yield for ACEL and SD-CP (1:1) was 60\% and 94-97\%, respectively, and drug content was 98-99\%. Saturation solubility for ACEL and SD-CP (1:1) was $6.2 \mu \mathrm{g} \mathrm{mL}-1$ and $25.68 \mu \mathrm{g} \mathrm{mL}^{-1}$, respectively, as compared to CEL $\left(3.5 \mu \mathrm{g} \mathrm{mL}^{-1}\right)$. Production yield (92 to $94 \%$ ), drug content ( 98 to $99 \%, \mathrm{~m} / \mathrm{m})$ and saturation solubility $(27.12 \mu \mathrm{g} \mathrm{mL}-1)$ of SD-CPT were comparable to SD-CP. Gupta et al. (10) have reported that a dispersion of $20 \% \mathrm{~m} / \mathrm{m}$ PVP with CEL resulted in maxima solubility enhancement. However, in the present study, the ratio of 1:1 parts by mass was selected for further studies. Higher concentration of PVP was used, since PVP will not only increase the solubility but also act as stabilizer by forming hydrogen bonding and improving the stability of SD-CP and SD-CPT powders during tableting. It acts as stabilizer by forming hydrogen bonding, which is one of the mechanisms for improved stability of SD-CP and SD-CPT powders even during tableting. The saturation solubility of PM-CPC $\left(9.26 \mu \mathrm{g} \mathrm{mL}^{-1}\right)$ was higher than ACEL. This is a result of improved wettability of drug particles due to the presence of hydrophilic polymer PVP. The amount of residual organic solvent in the samples was below the detection limit of TGA $(<0.05 \%, \mathrm{~m} / \mathrm{m})$. Tablet thickness varied with the ratio of the drug to stabilizers. Other tablet parameters such as uniformity of weight and friability were $85 \pm 5 \mathrm{mg}$ and $0.73 \pm 0.05 \%$ for all the tablets. All the tablets were compressed at a hardness of $49.0 \pm 5.0 \mathrm{~N}$.

DSC thermograms of initial and stability samples at different time periods of CEL, ACEL, SD-CP, SD-CPT, PM-CPC are shown in Fig. 1a. Pure CEL showed a sharp melting endotherm at $163.5^{\circ} \mathrm{C}$. ACEL showed a change in heat capacity at $51{ }^{\circ} \mathrm{C}$ indicating $T_{\mathrm{g}}$, followed by recrystallization exotherm at $101{ }^{\circ} \mathrm{C}$ and melting endotherm at $163.8^{\circ} \mathrm{C}$. SD-CP thermogram showed the absence of melting endotherm indicating complete drug amorphization during spray drying with PVP. SD-CPT thermogram was similar to SD-CP with no melting endotherm. Data suggest that spray drying of CEL-PVP with or without CAR resulted in celecoxib amorphization.

XRPD patterns of initial and stability samples at different time periods of CEL, ACEL, SD-CP, SD-CPT, PM-CPC are shown in Fig. 2a. The diffraction peaks at 18, 21, 24 and 26 ${ }^{\circ} 2 \theta$ are the characteristic peaks of crystalline CEL and are considered to be important for stability evaluation because these peaks appeared first when celecoxib started to recrystallize. The hump in the initial XRPD pattern of ACEL, SD-CP and SD-CPT indicates complete conversion of CEL to the amorphous form.

The XRPD patterns of ACEL showed characteristic peaks of crystalline CEL in the 15 day sample that subsequently increased on storage. The DSC pattern of the 1 month stability sample of ACEL showed a small melting endotherm at $163.8{ }^{\circ} \mathrm{C}$, which indicated partial recrystallization of the amorphous form during storage. The enthalpy of the melting endotherm of the 3 month stability sample was almost equivalent to CEL, indicating complete conversion into crystalline form. However, there was no change in DSC thermogram and XRPD pattern during 3 months of stability of SD-CP and SD-CPT. This confirms the stability of the amorphous form of celecixib in SD-CP and SD-CPT on storage, which may be due to the hydrogen bonding interaction of CEL with PVP (11) and the antiplasticizing effect of PVP (5). 
R. S. Dhumal et al.: Development of spray-dried co-precipitate of amorphous celecoxib containing storage and compression stabilizers, Acta Pharm. 57 (2007) 287-300.
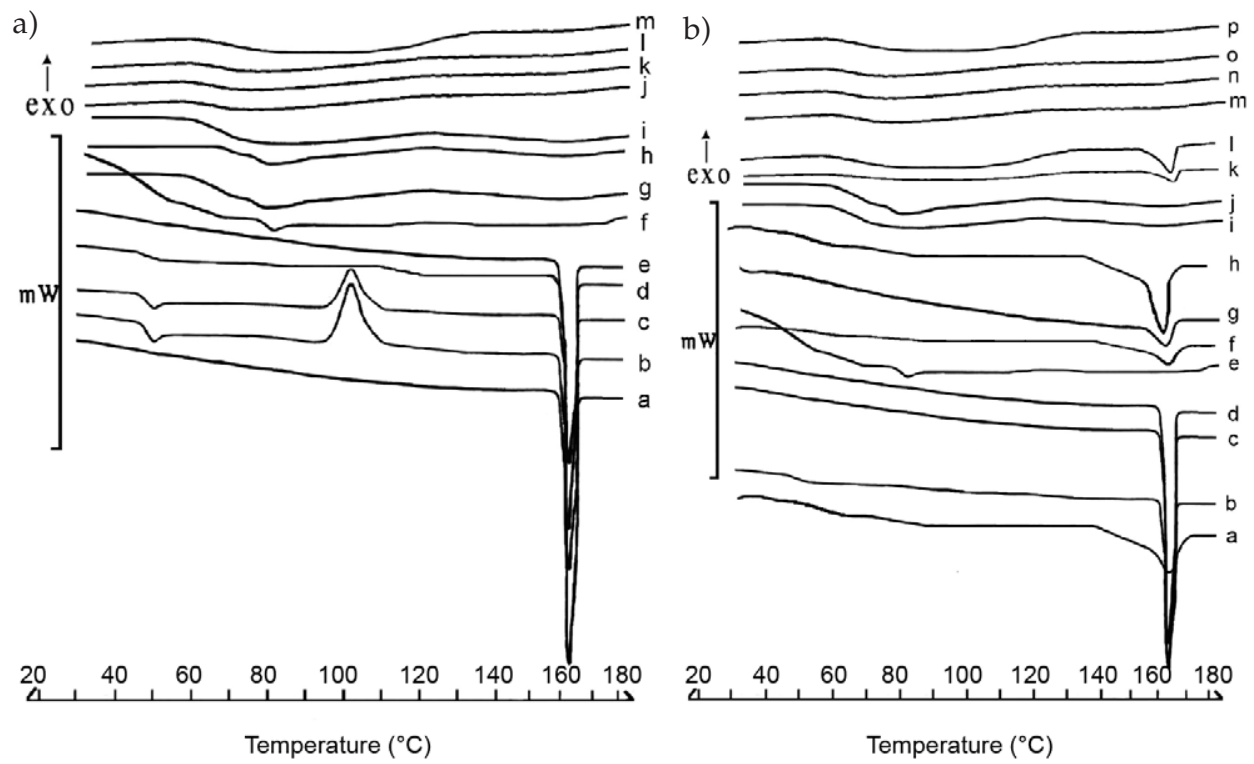

Fig. 1. a) DSC thermograms of powders: a - CEL; b - ACEL, initial; $c$ - ACEL, 15 days; $d$ - ACEL, 1 month; e - ACEL, 3 months; $\mathrm{f}$ - SD-CP, initial; $\mathrm{g}$ - SD-CP, 15 days; $\mathrm{h}$ - SD-CP, 1 month; $\mathrm{i}$ - SD-CP, 3 months; $\mathrm{j}$ - SD-CPT, initial; $\mathrm{k}$ - SD-CPT, 15 days; 1 - SD-CPT, 1 month; $\mathrm{m}$ - SD-CPT, 3 months.

b) DSC thermograms of tablet formulations: a - ACEL, initial; b - ACEL, 15 days; c - ACEL, 1 month; $\mathrm{d}$ - ACEL, 3 months; e - SD-CP, initial; f - SD-CP, 15 days; g - SD-CP, 1 month; h - SD-CP, 3 months; $\mathrm{i}$ - PM-CPC, initial: j - PM-CPC, 15 days; $\mathrm{k}$ - PM-CPC, 1 month; 1 - PM-CPC, 3 months; $\mathrm{m}$-SD-CPT, initial; $\mathrm{n}$ - SD-CPT, 15 days; o - SD-CPT, 1 month; $\mathrm{p}$ - SD-CPT, 3 months.

Initial DSC thermograms and XRPD patterns of CEL, ACEL, SD-CP, SD-CPT, PM-CPC tablets and their corresponding stability samples at different time periods are shown in Figs. $1 b$ and $2 b$, respectively. The initial thermogram of ACEL tablets showed a small melting endotherm at $163.8^{\circ} \mathrm{C}$, which increased on storage reflecting the stress-induced recrystallization of amorphous form during compression. Similarly, low intensity peaks of crystalline CEL were seen in the XRPD pattern, which increased on storage. SD-CP tablets showed no signs of recrystallization during compression, as evident from the DSC thermogram and XRPD profile, but showed crystallinity in the 15 day stability sample, which increased drastically on storage demonstrating inability of SD-CP to prevent recrystallization during compression and storage. Interaction between CEL and PVP imparted better protection against recrystallization of the amorphous form compared to ACEL alone. However, the tableting pressure provides the energy required for activation of the amorphous form and, hence, induces recrystallization, which is augmented during storage. This is the reason for the limited success of SD approach from the commercial point of view.

Both SD-CPT and PM-CPC tablets showed the absence of any crystallinity in initial samples, indicating prevention of crystallization during compression. But the tablets stored for 3 months showed a difference in recrystallization behavior. Tablets of PM-CPC showed protection against recrystallization during 1 month, which was clearly seen in 
a)

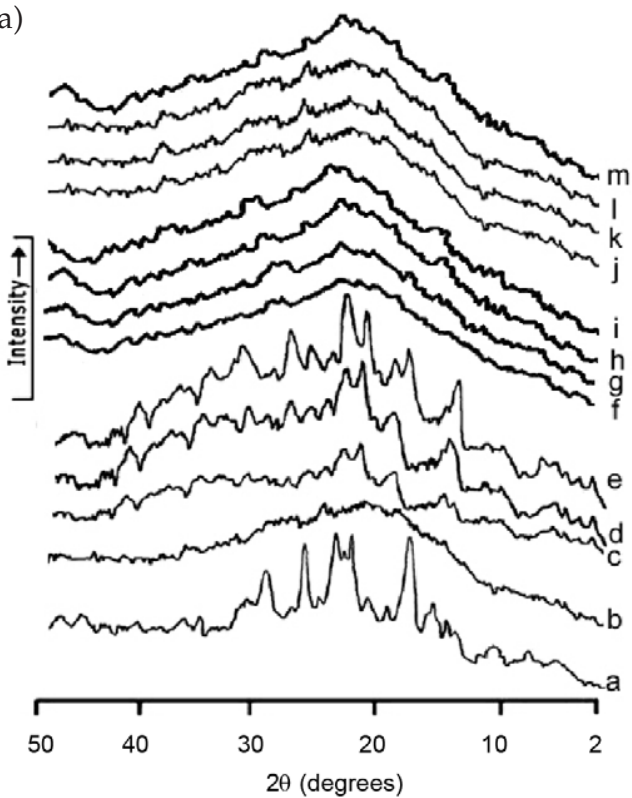

b)

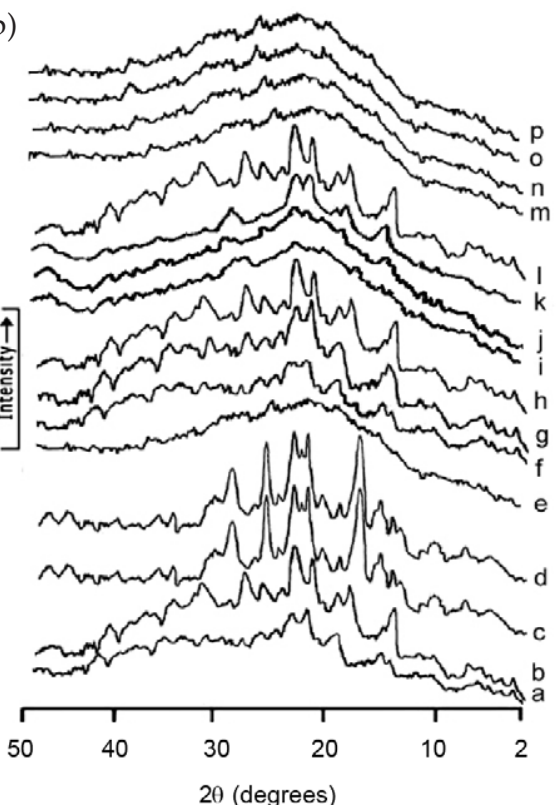

Fig. 2. a) XRPD patterns of powders: a - CEL; b - ACEL, initial; $\mathrm{c}-\mathrm{ACEL}, 15$ days; $\mathrm{d}-\mathrm{ACEL}, 1$ month; e - ACEL, 3 months; $\mathrm{f}$ - SD-CP, initial; $\mathrm{g}$ - SD-CP, 15 days; $\mathrm{h}$ - SD-CP, 1 month; i - SD-CP, 3 months; $\mathrm{j}$ - SD-CPT, initial; $\mathrm{k}$ - SD-CPT, 15 days; 1 - SD-CPT, 1 month; $\mathrm{m}$ - SD-CPT, 3 months.

b) XRPD patterns of tablet formulations: a - ACEL, initial; b - ACEL, 15 days; c - ACEL, 1 month; d - ACEL, 3 months; e - SD-CP, initial; $\mathrm{f}$ - SD-CP, 15 days; $\mathrm{g}$ - SD-CP, 1 month; $\mathrm{h}$ - SD-CP, 3 months; i - PM-CPC, initial; $\mathrm{j}$ - PM-CPC, 15 days; $\mathrm{k}$ - PM-CPC, 1 month; 1 - PM-CP, C 3 months; $\mathrm{m}$ - SD-CPT, initial; $\mathrm{n}$ - SD-CPT, 15 days; o - SD-CPT, 1 month; $\mathrm{p}$ - SD-CPT, 3 months.

the DSC thermogram (Fig. 3) and XRPD pattern (Fig. 4) but failed to prevent further recrystallization. However, there was no sign of recrystallization in stability samples of SD-CPT tablets. This was evident from no change in XRPD pattern and DSC thermogram of SD-CPT tablets stored for 3 months. This protection ability of SD-CPT may be attributed to the cushioning action provided by CAR, which releases mechanical stress in the form of expansion and stores less stress in tablets protecting the amorphous drug (20). Another reason for improved stability compared to PM may be the close proximity of ACEL with CAR in SD-CPT, which provides a better cushioning action during compression as a result of adsorption. Therefore, it could be concluded that the physical mixture of the amorphous form with viscoelastic carrier can only delay the recrystallization process but not fully prevent it. Therefore, this extraordinary stability of SD-CPT could be attributed both to the hydrogen bonding interaction between ACEL and PVP in the form of co-precipitate and the cushioning action of viscoelastic carrier on which ACEL is adsorbed.

The drug and polymer interaction often leads to noticeable changes in the IR spectra of SDs. IR spectra of ACEL, SD-CP, SD-CPT and PM were compared with the stan- 


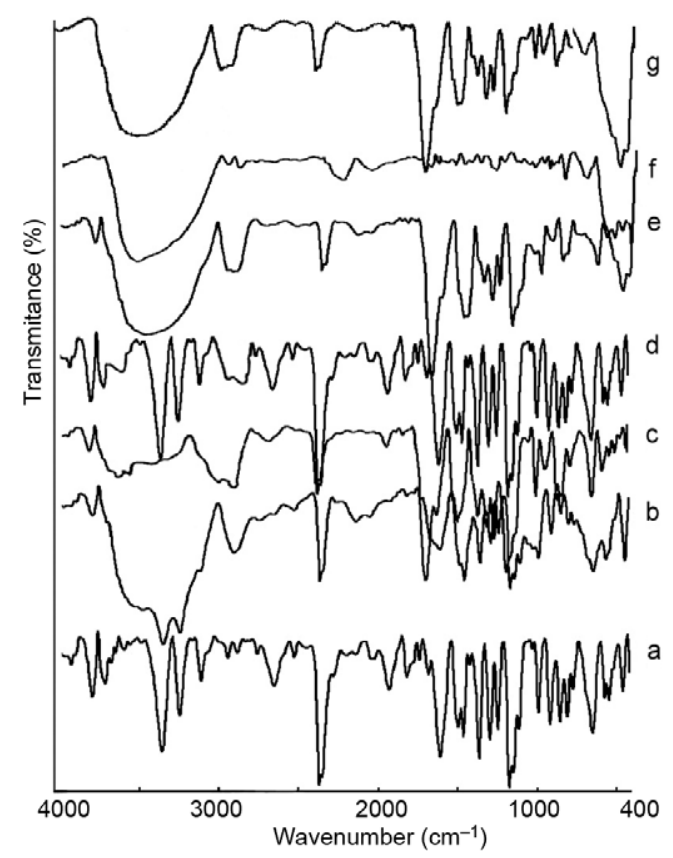

Fig. 3. Infrared spectra of: a) CEL; b) ACEL; c) PVP; d) PM-CP; e) SD-CP; f) CAR; g) SD-CPT.

dard spectrum for CEL (Fig. 3). The presence and absence of characteristic peaks associated with specific structural groups of the molecule were noted. The spectrum of CEL displayed characteristic peaks at 3232 and $3338 \mathrm{~cm}^{-1}$ (sharp doublet for N-H stretching vibrations), $1347 \mathrm{~cm}^{-1}$ ( $\mathrm{S}=\mathrm{O}$ asymmetric stretching vibrations) and $1230 \mathrm{~cm}^{-1}$ (C-F stretching vibrations). In case of ACEL, a slight shift in characteristic peaks was observed with no major difference in the overall spectrum. Sharp doublet for the N-H stretching vibration band was found to shift as a broader hump at a higher wavenumber, asymmetric vibration band for $\mathrm{S}=\mathrm{O}$ shifted at a lower wavenumber and $\mathrm{C}-\mathrm{F}$ stretching vibration shifted to a higher wavenumber. These changes strongly support the possibility of intermolecular hydrogen bonding. The spectrum of SD-CP showed notable broadening of N-H stretching vibration peaks characteristic of $\mathrm{CEL}$ and $\mathrm{C}=\mathrm{O}$ stretching vibration peaks characteristic of PVP. These observations indicated the possibility of hydrogen bonding between the $\mathrm{N}-\mathrm{H}$ group of CEL and the $\mathrm{C}=\mathrm{O}$ group of PVP. The peaks characteristic of CEL were almost unchanged in the low frequency region $\left(1000-400 \mathrm{~cm}^{-1}\right)$ of the spectra of SDs. This indicated that although the drug molecule is hydrogen bonded with the polymer through the sulfonamide group, the overall symmetry of the molecule is not affected to a noticeable extent. As indicated by XRPD, DSC and dissolution studies, intermolecular hydrogen bonding of CEL with PVP may be responsible for improved solubility and stability of SD-CP $(10,11)$. Interaction between CEL and CAR in SD-CPT cannot be explained by spectroscopic studies due to the overlapping of characteristic vibration peaks of CEL with broad peaks of carrageenan in this area. However, as CAR is only dispersed 
R. S. Dhumal et al.: Development of spray-dried co-precipitate of amorphous celecoxib containing storage and compression stabilizers, Acta Pharm. 57 (2007) 287-300.

and not solubilized in the solvent system, its ability to interact with CEL is limited and hence may not interfere with hydrogen bonding of ACEL with PVP, which is responsible for its stability in SD-CPT. This fact is also supported by DSC, XRPD and dissolution studies.

Dissolution profiles of initial and stability samples of ACEL and CEL in phosphate buffer ( $\mathrm{pH}$ 6.8) are shown in Fig. 4a. Amorphous form showed an increase in the dissolution profile ( $42 \%$ in $60 \mathrm{~min}$ ) compared to the crystalline form ( $20 \%$ in $60 \mathrm{~min}$ ). Dissolution profiles for SD-CP (58\% in $60 \mathrm{~min}$ ) and SD-CPT (62\% in $60 \mathrm{~min}$ ) were even higher than that of ACEL (Fig. 4b). The rate and extent of dissolution increased with increasing proportion of PVP, which was in accord with earlier reports (10). As compared to ACEL, SD-CP and SD-CPT showed improved dissolution rate. Better dissolution of SD-CPT can be correlated with better wetting and dispersibility of the system due to the hydrophilic polymer, PVP, increased surface area due to adsorption of ACEL on CAR in the form of co-precipitate and prevention of water mediated recrystallization of CEL in dissolution

a)

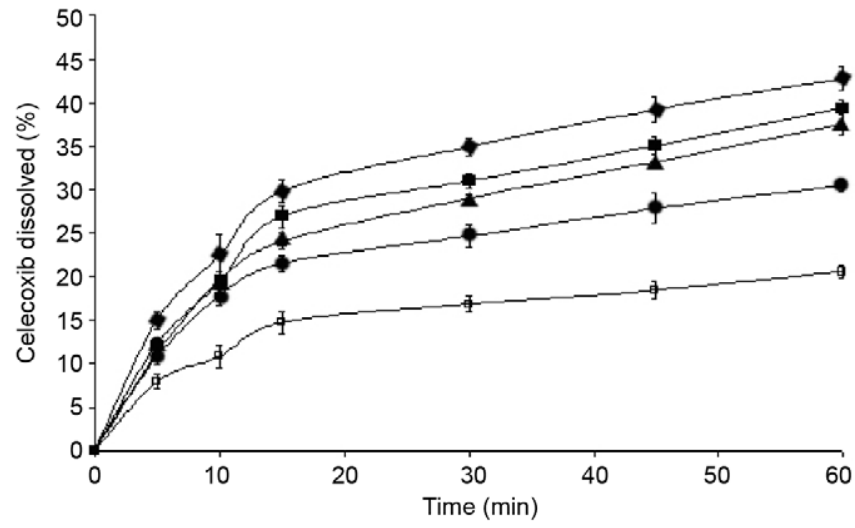

b)

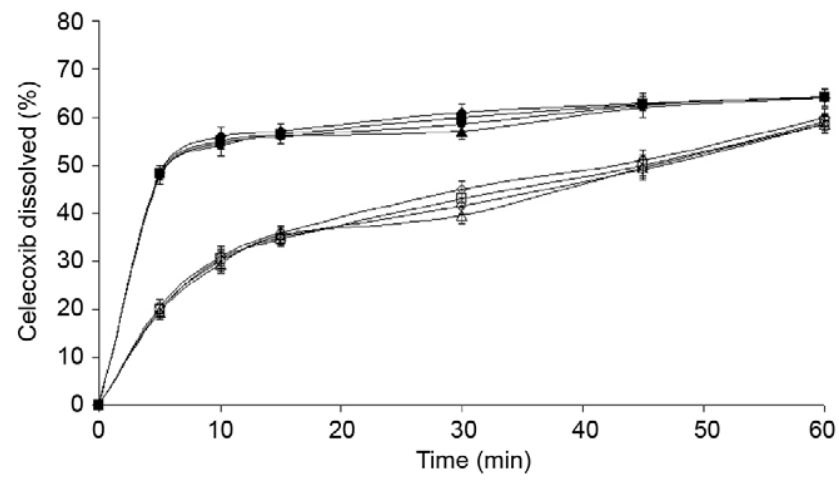

Fig. 4. Dissolution profiles of: a) CEL and ACEL powders: CEL, initial ( $\square$ ); ACEL, initial $(\diamond)$; ACEL, 15 days ( $\mathbf{\square})$; ACEL, 1 month $(\mathbf{\Lambda})$; ACEL, 3 months $(\mathbf{\bullet})$; b) SD-CP and SD-CPT powders: SD-CP, initial $(\diamond)$; SD-CP, 15 days $(\square)$; SD-CP, 1 month (o); SD-CP, 3 months $(\triangle)$; SD-CPT, initial $(\diamond)$ ); SD-CPT, 15 days $(\boldsymbol{\square})$; SD-CPT, 1 month $(\bullet)$; SD-CPT, 3 months $(\boldsymbol{\Delta})$ (mean \pm SD, $n=3$ ). 
media due to the hydrogen bonding interaction with PVP (2). PVP is a well known binder as well as a disintigrant; it therefore disturbs the matrix system of carrageenean or even does not allow formation of the matrix system, thereby nullifying the controlled release effect of carrageenean in SD-CPT. During 3 month stability testing ACEL has shown notable decrease in the dissolution profile, whereas SD-CP and SD-CPT dissolution profiles remained unchanged. This behavior is imparted to the system due to the hydrogen bonding interaction between CEL and PVP, as indicated by IR spectroscopy.

Dissolution profiles of initial and stability samples of the CEL and ACEL tablets are shown in Fig. 5a. The release profiles for initial tablet samples were in accord with those of the corresponding powders, except for the ACEL tablet. Tablets of ACEL showed a steep decrease in drug release on storage and the dissolution profile of the 1 month stability sample was nearly equivalent to the CEL tablet. This may be due to stress-induced recrystallization of ACEL. SD-CP tablet showed no change in the initial dissolution profile compared to the SD-CP powder (Fig. 5b). However, the solid dispersion with PVP

a)

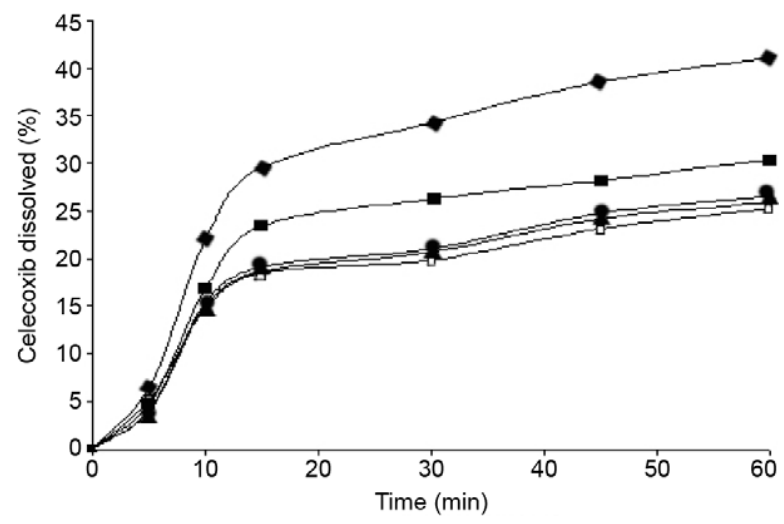

b)

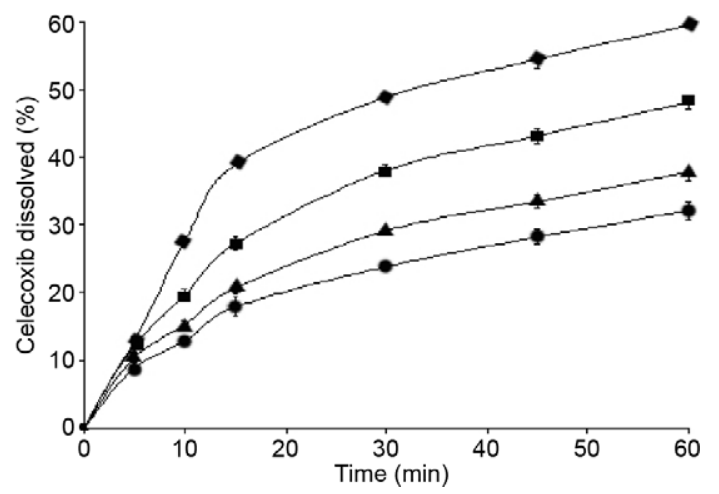

Fig. 5. Dissolution profiles of: a) CEL and ACEL tablets: CEL, initial ( $\square$ ); ACEL, initial ( $\bullet$ ); ACEL, 15 days $(\mathbf{\square})$; ACEL, 1 month $(\bullet)$; ACEL, 3 months $(\mathbf{\Delta})$; b) SD-CP tablets: initial $(\bullet)$; 15 days $(\mathbf{\square})$; 1 month $(\mathbf{\Delta})$; 3 months $(\bullet)$ (mean $\pm \mathrm{SD}, n=3$ ). 
R. S. Dhumal et al.: Development of spray-dried co-precipitate of amorphous celecoxib containing storage and compression stabilizers, Acta Pharm. 57 (2007) 287-300.

(SD-CP) when compressed into tablets was unable to protect recrystallization, which can be observed in stability. Dissolution profile of the 3 month sample was equivalent to the CEL tablet. Dissolution profiles of PM-CPC tablets were quite stable up to 1 month but decreased on further storage (Fig. 6a).

Tablets of SD-CPT also showed enhancement in dissolution, with $70 \%$ drug release within $60 \mathrm{~min}$ (Fig. 6b). Interestingly, the dissolution profiles of SD-CPT tablets were quite stable without any noticeable change even after 3 month storage. SD-CPT did not only show better dissolution but also imparted better protection than ACEL and SD-CP during compression and storage. Uniform adsorption of SD-CP on CAR may be the reason for improved protection of ACEL during compression. This keeps ACEL in the form of co-precipitate in intimate contact with CAR, which forms a cushioning layer imparting protection during compression. Further, the hydrogen bonding interaction between CEL and PVP also contributes to the storage stability of these tablets.

a)

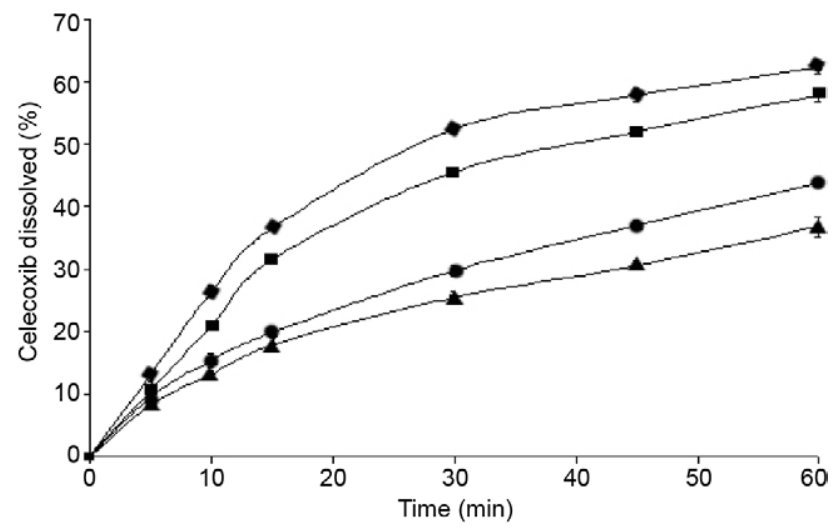

b)

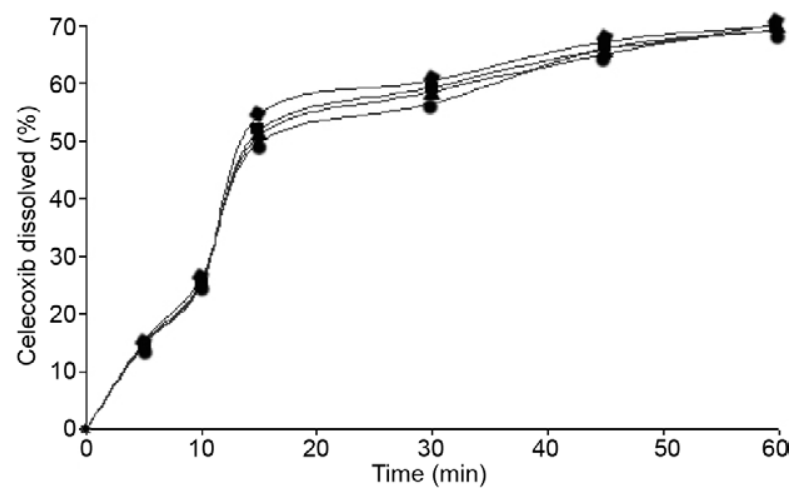

Fig. 6. Dissolution profiles of: a) PM-CPC tablets: initial ( $)$; 15 days ( $\mathbf{\square}) ; 1$ month $(\mathbf{\Delta})$; 3 months $(\bullet)$; b) SD-CPT tablets: initial $(\bullet)$; 15 days $(\boldsymbol{\square})$; 1 month $(\mathbf{\Delta})$; 3 months $(\bullet)$ (mean \pm SD, $n=3$ ). 


\section{CONCLUSIONS}

The present study has clearly revealed that the preparation of the solid dispersion of CEL with PVP and spray-dried co-precipitate with PVP and CAR led to enhanced dissolution and stability compared to amorphous CEL. Upon storage, SD-CP and SD-CPT powders have shown promising stability of the amorphous form. ACEL tablets could not withstand the compaction pressure and recrystallized on storage. Addition of viscoelastic agents like CAR in PM with ACEL and preparation of SD-CP improved compression stability but the protection ability was limited. SD-CPT tablets showed promising stability during tableting and on storage, which may be attributed to the hydrogen bonding interaction between CEL and PVP and the cushioning action provided by the viscoelastic polymer CAR during compression. The present study demonstrates the synergistic effect of combining two types of stabilizers, PVP and CAR, on the stability of ACEL during compression and storage as compared to their effect when used alone.

Acknowledgements. - The authors acknowledge the support of Lupin Research Park (Pune, India), FMC Corporation (New York, USA), Signet Chemical (Mumbai, India), BASF (Ludwigshafen, Germany) and Get-Rid Pharmaceuticals (Pune, India) for providing gift samples of celecoxib, carrageenan and other excipients, respectively. S.L.S. thanks CSIR (New Delhi, India) for providing financial support in the form of a senior research fellowship.

\section{REFERENCES}

1. A. R. Paradkar, B. Chauhan, S. Yamamura and A. P. Pawar, Preparation and characterization of glassy celecoxib, Drug Dev. Ind. Pharm. 29 (2003) 739-744; DOI: 10.1081/DDC-120021773.

2. P. Gupta, G. Chawala and A. K. Bansal, Physical stability and solubility advantage from amorphous celecoxib: The role of thermodynamic quantities and molecular mobility, Mol. Pharm. 1 (2004) 406-413; DOI: 10.1021/mp049938f.

3. M. K. Gupta., A. Vanwert and R. H. Bogner, Formation of physically stable amorphous drugs by milling with Neusilin, J. Pharm. Sci. 92 (2003) 536-551; DOI: 10.1002/jps.10308.

4. D. Q. Craig, P. G. Royall, V. L. Kett and M. L. Hopton, The relevance of the amorphous state to pharmaceutical dosage forms: glassy drugs and freeze dried systems, Int. J. Pharm. 179 (1999) 179-207; DOI: 10.1016/S0378-5173(98)00338-X.

5. A. A. Ambike, K. R. Mahadik, A. R. Paradkar, Stability study of amorphous valdecoxib, Int. J. Pharm. 282 (2004) 151-162; DOI: 10.1080/03639040500272025.

6. A. Paradkar, M. Maheshwari, R Kamble, I. Grimsey and P. York, Design and evaluation of celecoxib porous particles using melt sonocrystallization, Pharm. Res. 23 (2005) 1395-1400; DOI: 10.1007/s11095-006-0020-4.

7. D. Law, S. L. Krill, E. A. Schmitt, J. J. Fort, Y. H. Qiu, W. L. Wang and W. R. Porter, Physicochemical considerations in the preparation of amorphous ritonavir-poly(ethylene glycol) 8000 solid dispersions, J. Pharm. Sci. 90 (2001) 1015-1025; DOI: 10.1002/jps.1054.

8. H. Suzuki and H. Sunada, Influence of water-soluble polymers on the dissolution of nifedipine solid dispersions with combined carriers, Chem. Pharm. Bull. 46 (1998) 482-487.

9. S. L. Shimpi, B. Chauhan, K. R. Mahadik and A. R. Paradkar, Stabilization and improved in-vivo performance of amorphous etoricoxib using gelucier 50/13, Pharm. Res. 22 (2005) 1727-1734; DOI: $10.1007 /$ s11095-005-6694-1. 
R. S. Dhumal et al.: Development of spray-dried co-precipitate of amorphous celecoxib containing storage and compression stabilizers, Acta Pharm. 57 (2007) 287-300.

10. P. Gupta, V. K. Kakamanu and A. K. Bansal, Stability and solubility of celecoxib-PVP amorphous dispersions: molecular perspective, Pharm. Res. 21 (2004) 1762-1769; DOI:10.1023/B:PHAM. 0000045226.42859.b8.

11. P. Gupta, R. Thilagavathi, A. K. Chakraborti and A. K. Bansal, Role of molecular interaction in stability of celecoxib-PVP amorphous systems, Mol. Pharm. 2 (2005) 384-391.

12. J. Akbuga, A. Gursoy and F. Yetimoglu, Preparation and properties of tablets prepared from furosemide-PVP solid dispersion systems, Drug Dev. Ind. Pharm. 14 (1988) 2091-2108.

13. K. R. Morris, U. J. Griesserb, C. J. Eckhardt and J. G. Stowell, Theoretical approaches to physical transformations of active pharmaceutical ingredients during manufacturing processes, Adv. Drug Deliv. Rev. 48 (2001) 91-114; DOI: 10.1016/S0169-409X(01)00100-4.

14. T. Matsumoto, N. Kaneniwa, S. Higuchi and M. Otsuka, Effects of temperature and pressure during compression on the polymorphic transformation and crushing strength of chlorpropamide tablets, J. Pharm. Pharmacol. 43 (1991) 74-78.

15. V. Andronis and G. Zografi, The molecular mobility of supercooled amorphous indomethacin as a function of temperature and relative humidity, Pharm. Res. 15 (1998) 835-842.

16. M. Otsuka, M. Nakanishi and Y. Matsuda. Effects of crystalline form on compression mechanism of phenobarbital polymorphs, Drug Dev. Ind. Pharm. 25 (1999) 205-215.

17. C. Lefebvre, A. M. Guyot-Hermann, M. Draguet-Bruchmans and R. Bouche, Polymorphic transitions of carbamazepine during grinding and compression, Drug Dev. Ind. Pharm. 12 (1986) 1913-1927.

18. H. Chan and E. Doelker, Polymorphic transformation of some drugs under compression, Drug Dev. Ind. Pharm. 11 (1985) 315-332.

19. A. G. Schmidt, S. Wartewig and K. M. Picker, Potential of carrageenan to protect drugs from polymorphic transformation, Eur. J. Pharm. Biopharm. 56 (2003) 101-110; DOI: 10.1016/S09396411(03)00037-7.

20. K. M. Picker, »Soft tableting «: A new concept to tablet pressure sensitive materials, Pharm. Dev. Technol. 9 (2004) 107-121; DOI: 10.1081/PDT-120027426.

21. United States Pharmacopoeia 24, National Formulary 19, USP Convention, Rockville 2000.

$S A \check{Z} E T A K$

\section{Razvoj koprecipitata amorfnog celekoksiba sa stabilizatorima metodom sprej-sušenja}

RAVINDRA S. DHUMAL, SHAMKANT L. SHIMPI i ANANT R. PARADKAR

Cilj rada bio je pripraviti u što manje proizvodnih stupnjeva amorfni sustav iz kojeg ljekovita tvar neće kristalizirati za vrijeme proizvodnje i skladištenja. Metodom sprej-sušenja pripravljeni su amorfni celekoksib, čvrsta disperzija celekoksiba s polivinil pirolidonom (PVP) i koprecipitat s PVP i karagenanom (CAR) u različitim omjerima. Dobiveni pripravci su zatim komprimirani u tablete iz kojih je praćeno oslobađanje ljekovite tvari. DSC i XRPD analize ukazuju na amorfnu formu celekoksiba, a IR spektroskopija na vodikove veze između celekoksiba i PVP. Oslobađanje celekoksiba iz čvrstih disperzija i koprecipitata bilo je poboljšano u odnosu na celekoksib i amorfni celekoksib. Amorfni celekoksib nije bio stabilan tijekom skladištenja dok su čvrste disperzije i koprecipitati bili stabilni tijekom tri mjeseca. Tablete čvrstih disperzija celekoksiba s PVP i fizičke smjese s 
R. S. Dhumal et al.: Development of spray-dried co-precipitate of amorphous celecoxib containing storage and compression stabilizers, Acta Pharm. 57 (2007) 287-300.

PVP i karagenanom bile su otpornije na kristalizaciju nego amorfni celekoksib za vrijeme kompresije, ali ne i tijekom skladištenja. Tablete s koprecipitatom s PVP i karagenanom imale su sličan profil oslobađanja, a u njima se za vrijeme skladištenja nije kristalizirala ljekovita tvar. Ova iznimna stabilnost može se objasniti viskoelastičnošću polimera CAR i vodikovim vezama između celekoksiba i PVP. Kombinacijom dvaju stabilizatora postignut je sinergistički učinak.

Ključne riječi: celekoksib, amorfna tvar, čvrsta disperzija, koprecipitat, PVP, karagenan, kompresija, stabilnost, tabletiranje

Department of Pharmaceutics, Bharati Vidyapeeth Deemed University, Poona College of Pharmacy and Research Centre, Erandawane, Pune-411038, Maharashtra, India 